\section{Other treatment modalities}

Recent studies using maternal intravenous immunoglobulin have shown some benefit in severe cases of RhD incompatibility. ${ }^{27} 28$ The mechanism of action is still not well understood but may entail downregulation of the maternal immune response, placental antigenic blockade, or antigenic blockade at the level of the fetal reticulo-endothelial system. Whatever the mechanism, it is not uniformly effective in inhibiting haemolysis, but when it does, serum bilirubin concentrations fall. This treatment modality is appropriate only in selected cases-for example, very early disease. It may prolong the time interval before the first intrauterine treatment is required. Immunisation to paternal leucocytes in an animal model has been described and has been shown to prevent haemolytic disease. ${ }^{29}$ This technique, although showing promise, is still not yet in clinical use.

\section{Conclusions}

Although the incidence of haemolytic disease of the newborn has decreased and is no longer a major cause of perinatal mortality, vigilance is still required. Far fewer cases mean less available experience to manage such complicated pregnancies. A strong argument exists for centralising the management of these cases in a few fetal medicine centres that perform enough invasive procedures to maintain skills. Immune therapy in established cases of alloimmunisation show promise but has yet to be translated into routine clinical management.

1 Bowman JM. The prevention of Rh immunization. Transfus Med Rev 1988 2:129-50.

2 Landsteiner K, Weiner AS. An agglutinable factor in human blood recognised by immune sera for Rhesus blood. Proc Soc Exp Biol Med 1940 43:223.

3 Bowman JM, Pollock JM, Penston LE. Fetomaternal transplacental hemorrhage during pregnancy and after delivery. Vox Sang 1986;51:117-21.

Royal College of Obstetricians and Gynaecologists. Green top guidelines Anti-D immunoglobulin for Rh prophylaxis. London: RCOG, 2002.

5 National Institute for Clinical Excellence. Guidelines. Pregnancy- routine National Institute for Clinical Excellence. Guidelines. Pregnancy - routine anti-D prophylaxis for rhesus negative women (No. 41). London: NICE, 2002 Nicolaides KH, Rodeck CH. Maternal serum anti-D antibody concentration and assessment of rhesus isoimmunisation. BMJ 1992;304:1155-6.
Lo YM, Bowell PJ, Selinger M, Mackenzie IZ, Chamberlain P, Gillmer MD, et al. Prenatal determination of fetal rhesus D status by DNA amplification of peripheral blood of rhesus-negative mothers. Ann N Y Acad Sci 1994;731:229-36.

8 Finning KM, Martin PG, Soothill PW, Avent ND, et al. Prediction of fetal D status from maternal plasma: introduction of a new noninvasive fetal RHD genotyping service. Transfusion 2002;42:1079-85.

9 Mari G, Deter RL, Carpenter RL, Rahman F, Zimmerman R, Moise KJ Jr, et al. Noninvasive diagnosis by Doppler ultrasonography of fetal anemia due to maternal red-cell alloimmunization. Collaborative Group for due to maternal red-cell alloimmunization. Collaborative Group for
Doppler Assessment of the Blood Velocity in Anemic Fetuses. $N$ Engl J

10 Bullock R, Martin WL, Coomarasamy A, Kilby MD. Prediction of fetal anemia in pregnancies with red-cell alloimmunization: comparison of middle cerebral artery peak systolic velocity and amniotic fluid OD450. Ultrasound Obstet Gynecol 2005;25:331-4.

11 Liley AW. Liquor amnil analysis in the management of the pregnancy complicated by resus sensitization. Am J Obstet Gynecol 1961;82:1359-70.

12 Maxwell DJ, Johnson P, Hurley P, Neales K, Allan L, Knott P. Fetal blood sampling and pregnancy loss in relation to indication. Br J Obstet Gynaecol 1991. 98(9):892-7.

13 Klumper FJ, van Kamp IL, Vandenbussche FP, Meerman RH, Oepkes D, Scherjon SA, et al. Benefits and risks of fetal red-cell transfusion after 32 Scherjon SA, et al. Benefits and risks of fetal red-cell transfusion

14 Pattison NS, Roberts AB, Mantell N. Intrauterine fetal transfusion, 1963 90. Ultrasound Obstet Gynecol 1992;2:329-32.

15 Grab D, Paulus WE, Bommer A, Buck G, Terinde R. Treatment of fetal erythroblastosis by intravascular transfusions: outcome at 6 years. Obste Gynecol 1999;93:165-8.

16 van Kamp IL, Klumper FJ, Bakkum RS, Oepkes D, Meerman RH, Scherjon $\mathrm{SA}$, et al. The severity of immune fetal hydrops is predictive of feta outcome after intrauterine treatment. Am J Obstet Gynecol 2001;185:668-73.

17 De Groot CJ, Oepkes D, Egberts J, Kanhai HH. Evidence of endothelium involvement in the pathophysiology of hydrops fetalis? Early Hum Dev 2000;57(3):205-9.

18 Berger HM, Lindeman JH, van Zoeren-Grobben D, Houdkamp E, Schrijver J, Kanhai HH. Iron overload, free radical damage, and rhesus haemolytic disease. Lancet 1990;335:933-6.
19 Schumacher B, Moise KJ Jr. Fetal transfusion for red blood cell alloimmunization in pregnancy. Obstet Gynecol 1996;88:137-50.

20 Peterec SM. Management of neonatal Rh disease. Clin Perinatol 1995, 22:561-92.

21 Millard DD, Gidding SS, Socol ML, MacGregor SN, Dooley SL, Ney JA, et al. Effects of intravascular, intrauterine transfusion on prenatal and postnatal hemolysis and erythropoiesis in severe fetal isoimmunization. J Pediatr 1990;117:447-54.

22 Scaradavou A, Inglis S, Peterson P, Dunne J, Chervenak F, Bussel J. Suppression of erythropoiesis by intrauterine transfusions in hemolytic disease of the newborn: use of erythropoietin to treat the late anemia. J Pediatr 1993;123:279-84.

23 Saade GR, Moise KJ, Belfort MA, Hesketh DE, Carpenter RJ. Fetal and neonatal hematologic parameters in red cell alloimmunization: predicting the need for late neonatal transfusions. Fetal Diagn Ther 1993;8:161-4

24 Ovali F, Samanci N, Dagoglu T. Management of late anemia in Rhesus hemolytic disease: use of recombinant human erythropoietin (a pilo study). Pediatr Res 1996;39:831-4.

25 Hudon L, Moise KJ Jr, Hegemier SE, Hill RM, Moise AA, Smith EO, et al. Long-term neurodevelopmental outcome after intrauterine transfusion for the treatment of fetal hemolytic disease. Am J Obstet Gynecol 1998;179: 858-63.

26 Cannon M, Jones PB, Murray RM. Obstetric complications and schizophrenia: historical and meta-analytic review. Am J Psychiatry 2002; 159:1080-92.

27 Voto LS, Mathet ER, Zapaterio JL, Orti J, Lede RL, Margulies M. High-dose gammaglobulin (IVIG) followed by intrauterine transfusions (IUTs): a new alternative for the treatment of severe fetal hemolytic disease. J Perinat Med 1997;25:85-8.

28 Troncek DF, Procter JL, Moses L, Bolan C, Pomper GJ, Conroy-Cantilena C, et al. Intravenous $\mathrm{Rh}$ immune globulin prevents alloimmunization in D-granulocyte recipients but obscures the detection of an alloanti-K. Immunohematology 2001;17:37-41.

29 Whitecar PW, Farb R, Subramanyam L, Dorman K, Balu RB, Moise KJ Jr, et al, Paternal leukocyte alloimmunization as a treatment for hemolytic disease of the newborn in a rabbit model. Am J Obstet Gynecol 2002;187:977-80.

(Accepted 13 April 2005)

\section{Corrections and clarifications}

Principles for international registration of protocol information and results from human trials of health related interventions: Ottawa statement (part 1)

A wrong URL in the penultimate paragraph of this Education and Debate article by Karmela

Krleža-Jerić and colleagues persisted to publication (BMJ 2005;330:956-8, 23 Apr). Anyone wishing to contribute to the Ottawa statement on trial registration can do so via http://ottawagroup.ohri.ca. However, although the URL is wrong in the bmj.com version of this article (as well as in the printed journal), the hyperlink does connect to the correct website.

\section{Two drug firms advertised to patients}

We read our British National Formulary too quickly when checking the generic name for Seretide in this News article by Zosia Kmietowicz (BMJ 2005;330:805, 9 Apr). Seretide (GlaxoSmithKline) contains not only fluticasone propionate (as we said) but also salmeterol xinafoate.

FDA warns about using antipsychotic drugs for dementia Again we got some drug details wrong. In this News article by Jeanne Lenzer (BMJ 2005;330:922-3, 23 Apr) we said that Symbyax (Lilly) contained only olanzapine, whereas in fact it also contains fluoxetine hydrochloride.

National survey of UK emergency endoscopy units We took someone else's error and made it ours in the "What is already known on this topic" box in Andrew Douglass and colleagues' survey (BMJ 2005:1000-1,30 Apr ). Endoscopy was done too late in $7 \%$ of cases (not 79\%, as we stated). The incorrect percentage came from the scoping report of the National Confidential Enquiry into Patient Outcome and Death. 